\title{
Peran Guru Pendidikan Agama Hindu dalam Membangun Nilai Karakter Siswa melalui Implementasi Tri Hita Karana
}

\author{
I Gede Arsa Arimbawa ${ }^{1}$, Nengah Bawa Atmadja ${ }^{2}$ I Nyoman Natajaya ${ }^{3}$ \\ ${ }^{123}$ Administrasi Pendidikan, Program Pascasarjana \\ Universitas Pendidikan Ganesha \\ Singaraja, Indonesia \\ e-mail: arsa.arimbawa@pasca.undiksha.ac.id', bawa.atmadja@pasca.undiksha.ac.id², \\ nyoman.natajaya@pasca.undiksha.ac.id ${ }^{3}$
}

\begin{abstract}
Abstrak
Tujuan penelitian ini yaitu (1) untuk mengetahui Nilai Tri Hita Karana belum bisa ditanamkan secra optimal di SMK N 3 Singaraja, (2) menganalisis peran guru pendidikan agama hindu dalam mengimplementasikan Tri Hita Krana sebagai upaya membangun nilai karakter siswa di SMK N 3 Singaraja, (3) menganalisis persepsi siswa terhadap Tri Hita Karana sebagai landasan budiperkerti dalam Agama Hindu di SMK N 3 Singaraja.Objek dalam penelitian ini adalah SMK N 3 Singaraja, sedangkan subjeknya yaitu guru agama hindu kelas XI TIPTL. Data dalam penyusunan penelitian ini dikumpulkan melalui observasi, kuesioner, dan dokumentasi. Data yang terkumpul selanjutnya dianalisis menggunakan metode deskriptif kualitatif. Hasil penelitian ini yaitu: (1) Tri Hita Karana belum bisa ditanamkan secara optimal di SMK N 3 Singaraja karena faktor internal dan faktor eksternal. (2) Peran guru pendidikan Agama Hindu dalam mengimplementasikan Tri Hita Karana sebagai upaya membangun nilai karakter siswa di sekolah ditananamkan dengan mengintegrasikan ke setiap materi pembelajaran, pengembangan budaya sekolah, dan melalui kegiatan ekstra kurikuler. (3) Persepsi siswa terhadap Tri Hita Karana sebagai landasan Budipekerti dalam Agama Hindu mendapat respon yang baik sebab siswa memperoleh manfaat dari pembelajaran Tri Hita Karana.
\end{abstract}

Kata kunci: Peran guru pendidikan Agama Hindu, Tri Hita Karana, Nilai Karakter

\section{Abstract}

The purpose of this research are (1) for knowing the values of Tri Hita Karana that can not be instilled optimally yet in SMK N 3 Singaraja, (2) analyze the role of Hindu religious education teachers in implementing the Tri Hita Krana as an effort to build the character values of students in SMK N 3 Singaraja, (3) analyze the students' perception of Tri Hita Karana as the base of morality in Hinduism in SMK N 3 Singaraja. The object of this research is SMK 3 Singaraja, and the subjects are the teachers of Hindu religion $11^{\text {th }}$ 's grade of TIPTL. Compiled data of this study were collected by observation, questionnaires, and documentation. The collected data were analyzed using qualitative descriptive methods. The results of this study are: (1) Tri Hita Karana can not be invested optimally yet in SMK N 3 Singaraja because of internal factors and external factors. (2) Hindu Religious education teacher's role in implementing the Tri Hita Karana in an effort to build character values of students in school are instilled by integrating into every learning materials, school cultural development, and by extracurricular activities. (3) Students' perception of Tri Hita Karana as the base of Budipekerti in Hinduism gets some good response because students are getting the benefit from learning Tri Hita Karana.

Keywords: The role of the Hindu education teacher, Tri Hita Karana, Character Values 


\section{Pendahuluan}

Undang-Undang No. 20 Tahun 2003 tentang Sistem Pendidikan Nasional Pasal 2 menyebutkan bahwa pendidikan nasional berfungsi mengembangkan kemampuan dan membentuk watak serta peradaban bangsa yang bermartabat dalam rangka mencerdaskan kehidupan bangsa, bertujuan untuk mengembangkan potensi peserta didik agar menjadi manusia yang beriman dan bertakwa kepada Tuhan Yang Maha Esa, berakhlak mulia, sehat, berilmu, cakap, kreatif, mandiri, dan menjadi warga negara yang demokratis serta bertanggung jawab. Pada era sekarang ini tujuan tersebut sebenarnya sudah dapat dilihat wujudnya, namun realita menunjukkan bahwa pada era globalisasi yang ditandai dengan perubahan di berbagai sektor kehidupan yang begitu cepat, bangsa Indonesia mengalami beberapa masalah. Kondisi yang sangat menyedihkan tersebut masih ditambah dengan merosotnya moralitas, dan spiritual. Demikian juga nilai-nilai kejujuran, kerapuhan karakter, kerapuhan identitas, krisis kepercayaan dan terjadinya degradasi moral pada remaja dan menurunnya mutu pendidikan yang ditengarai salah satunya di akibatkan oleh derasnya pengaruh era globalisasi. Hal ini di tenggarai oleh lemahnya pengawasan dari semua lapisan masyarakat baik dari bawah sampai masyarakat tingkat atas. Terjadinya degradasi terhadap mutu pendidikan sehingga memunculkan bentuk tindakan kekerasan, korupsi, disintegrasi, degradasi moral, krisis kepercayaan, yang menimbulkan kerisauan diberbagai kalangan masyarakat terhadap perilaku manusia Indonesia yang dianggap telah melakukan penyimpangan dari nilai-nilai luhur agama, budaya, dan falsafah bangsa yang seakan-akan telah terkubur oleh kebohongan dan tipu daya manusia di jaman global.

Degradasi moral juga telah terjadi disekolah-sekolah seperti, kondisi kehidupan siswa tampak sangat menyedihkan, sebagian kurang memiliki kesadaran terhadap lingkungan, baik alam maupun ke sesama manusia, siswa lebih suka bergosip dari pada mendengarkan ceramah yang menyejukkan jiwa, lebih suka membaca novel porno dari pada membaca untaian indah kitab suci dan ajaran-ajaran agung. Seorang guru yang seharusnya mendapat penghormatan sebagaimana mestinya dilupakan, tidak lagi berhati-hati bergaul sesuai anjuran kitab suci bahkan cendrung menjauhi orang-orang bijak dan orang-orang spiritual, yang dianggapnya ketingalan zaman dan menggelikan (Aryadharma, 2005:4-5).

Untuk mengatasi hal tersebut di atas, maka perlu dilakukan kembali penanaman nilainilai agama dan budaya serta pendidikan karakter. Secara sadar dan terencana dipandang perlu mengembangkan konsep sadar budaya dan penanaman nilai-nilai karakter oleh karena itu pemberdayaan lembaga pendidikan formal dan nonformal perlu lebih ditingkatkan untuk membangun nilai karakter siswa melalui implementasi Tri Hita Karana.

SMK N 3 Singaraja merupakan salah satu lembaga pendidikan formal negeri, yang berlokasi di Kota Singaraja. Berdasarkan pengamatan yang dilakukan, sebagian kecil dari siswa di SMK Negeri 3 Singaraja masih terlihat kurang memiliki kedisiplinan sebagaimana tercermin dari ajaran Tri Hita Karana. Seperti contoh, kurang pedulinya dengan lingkungan dengan membuang sampah sembarangan, baik didalam maupun diluar sekolah; Beberapa murid masih terlihat tidak hormat terhadap gurunya, tidak mendengarkan pelajaran dengan baik; Beberapa kali siswa terlihat tidak melaksanakan persembahyangan dengan baik, seperti main-main dan tidak melaksanakan persembahyangan sebagaimana mestinya.

Jika Tri Hita Karana ditanamkan maka tidak akan terjadi degradasi moral seperti fenomena-fenomena yang telah terjadi saat ini. Sekolah yang merupakan lembaga pendidikan seolah-olah menjadi tidak berdaya menghadapi kenyataan ini, sekolah selalu menjadi kambing hitam dari merosotnya watak dan karakter bangsa. Padahal sekolah sendiri menghadapi berbagai masalah menyangkut kurikulum yang overload, fasilitas sarana prasarana yang kurang memadai, kualitas Sumber Daya Manusia pengelola sekolah belum merata.

Kekurangan ini perlu ditinjau lebih lanjut dengan melihat persepsi siswa terhadap model pembelajaran Agama Hindu, termasuk penanaman nilai Tri Hita Karana dalam proses pembelajaran. Dengan mendapatkan pandangan siswa maka segala kekurangan dan kelemahan sistem akan dapat terlihat lebih jelas karena dalam sistem pendidikan siswa merupakan konsumen yang harus dirubah dan diarahkan sesuai dengan tujuan sekolah sebagai lembaga pendidikan.

Oleh karena itu pendidikan yang mengacu pada Pendidikan nilai karakter dan spiritualitas disekolah sangat tepat diajarkan melalui implementasi konsep ajaran Tri Hita Karana, karena ajaran Tri Hita Karana membangun sikap hidup yang seimbang dan harmonis dengan Tuhan, dengan sesama manusia, dan dengan alam lingkungan, maka akan terwujud kehidupan yang bahagia lahir batin (Wiana, 2007:5). 


\section{Tri Hita Karana}

Tri Hita Karana berarti tiga penyebab kebahagiaan (three couses of goodness) yang berasal dari kata Tri yang artinya tiga, Hita artinya kebahagiaan, dan Karana artinya penyebab. Menciptakan sebuah kebahagiaan yang diinginkan harus melalui proses penyelarasan hubungan antara tiga unsur, yaitu harmonis dalam hubungan manusia dengan alam, harmonis dalam hubungan manusia dengan manusia, dan harmonis dalam hubungan manusia dengan Tuhan. Jadi, keseimbangan/ harmonis (equilibrium) adalah budaya yang diutamakan. Kearifan lokal inilah yang menjadi wahana pengembangan dalam hubungan manusia dengan alam (Palemahan), manusia dengan manusia (Pawongan) dan manusia dengan Tuhan (Parahyangan) untuk mencapai kebahagian yang sempurna (Pageh, 2011: 15; Parimartha, 2011: 44).

Adapun makna dari penerapan tiga unsur Tri Hita Karana yakni Parahyangan, Palemahan dan Pawongan antara lain:

Parahyangan: hubungan manusia denga Tuhan (Parahyangan) didasari karena manusia adalah ciptaan Tuhan, sedangkan Atman yang ada dalam diri manusia merupakan percikan sinar suci kebesaran Tuhan yang menyebabkan manusia dapat hidup. Dilihat dari segi ini sesungguhnya manusia itu berhutang nyawa terhadap Tuhan. Oleh karena itu setiap manusia wajib berterima kasih, berbhakti dan selalu sujud kepada Tuhan Yang Maha Esa. Rasa terima kasih dan sujud bhakti itu dapat dinyatakan dalam bentuk puja dan puji terhadap kebesaranNya.

Palemahan: hubungan antara manusia dengan alam terlahir dari konsep bahwa manusia hidup dalam suatu lingkungan, yaitu alam. Alam itulah lingkungan manusia dan tanpa alam manusia tidak akan bisa memenuhi kebutuhan hidupnya. Manusia dengan demikian sangat tergantung kepada lingkungannya. Oleh karena itu, manusia harus selalu memperhatikan situasi dan kondisi lingkungannya. Lingkungan harus selalu dijaga dan dipelihara serta tidak dirusak.

Pawongan: hubungan antara manusia dengan manusia didasari oleh hakikat manusia sebagai mahluk sosial. Sebagai mahluk sosial, manusia tidak dapat hidup menyendiri. Mereka memerlukan bantuan dan kerja sama dengan orang lain. Karena itu hubungan antara sesamanya harus selalu baik dan harmoni. Hubungan antar manusia harus diatur dengan dasar saling asah, saling asih dan saling asuh, yang artinya saling menghargai, saling mengasihi dan saling membimbing. Hubungan antar keluarga di rumah harus harmonis, begitu juga dengan masyarakat. Hubungan baik ini akan menciptakan keamanan dan kedamaian lahir batin di masyarakat.

\section{Deskripsi Teori}

\section{Kesulitan Belajar}

Kesulitan belajar adalah suatu keadaan yang menyebabkan siswa tidak dapat belajar sebagaimana mestinya (Dalyono, 1997:229). Ada beberapa kasus kesulitan dalam belajar, sebagaimana yang telah dikemukakan oleh Abin Syamsudin M, yaitu : (1) Kasus kesulitan dengan latar belakang kurangnya motivasi dan minat belajar. (2) Kasus kesulitan yang berlatar belakang sikap negatif terhadap guru, pelajaran, dan situasi belajar. (3) Kasus kesulitan dengan latar belakang kebiasaan belajar yang salah. (4) Kasus kesulitan dengan latar belakang ketidakserasian antara kondisi obyektif keragaman pribadinya dengan kondisi obyektif instrumental impuls dan lingkungannya.

(http://www.sarjanaku.com/2011/08/pengertiankesulitan-belajar.html)

Jadi kesulitan belajar adalah segala sesuatu yang membuat tidak lancar (lambat) atau menghalangi seseorang dalam mempelajari, memahami serta menguasai sesuatu untuk dapat mencapai tujuan. Adanya kesulitan belajar dapat ditandai dengan prestasi yang rendah atau di bawah ratarata yang dicapai oleh kelompok kelas, hasil yang dicapai tidak seimbang dengan usaha yang dilakukan dan lambat dalam melakukan tugas belajar. Siswa yang mengalami kesulitan belajar akan sukar dalam menyerap materi-materi pelajaran yang disampaikan oleh guru sehingga ia akan malas dalam belajar, serta tidak dapat menguasai materi, menghindari pelajaran, serta mengabaikan tugas-tugas yang diberikan guru. Menurut Dalyono (1997:239) menjelaskan faktor-faktor yang menimbulkan kesulitan dalam belajar, yaitu faktor intern atau internal merupakan faktor yang timbul dari dalam diri seseorang, yang terjadi karena dua penyebab, yaitu: 1) Sebab yang bersifat fisik : karena sakit, karena kurang sehat atau sebab cacat tubuh; 2) Sebab yang bersifat karena rohani : intelegensi, bakat, minat, motivasi, faktor 
kesehatan mental, tipe-tipe khusus seorang pelajar. Dan faktor ekstern atau eksternal merupakan faktor yang timbul dari luar diri seseorang, yang terjadi karena tiga penyebab, yaitu: 1) Faktor Keluarga, yaitu tentang bagaimana cara mendidik anak, hubungan orang tua dengan anak. Suasana yang sangat gaduh atau ramai. Serta faktor ekonomi keluarga keadaan yang kurang mampu juga bisa mepengaruhi kesulitan belajar; 2) Faktor Sekolah, guru tidak berkualitas juga menjadi penyebabnya, hubungan guru dengan murid kurang harmonis, metode mengajar yang kurang disenangi oleh siswa. Serta faktor alat-alat pelajaran yang kurang lengkap, tempat atau gedung, dan juga kurikulum yang kurang baik dipahami guru, dan; 3) Faktor mass media dan lingkungan sosial, meliputi bioskop, TV, surat kabar, majalah, bukubuku komik. Lingkungan sosial meliputi teman bergaul, lingkungan tetangga, aktivitas dalam masyarakat..

\section{Implementasi Tri Hita Karana Dalam Membangun Nilai Karakter Siswa}

Implementasi konsep ajaran Tri Hita Karana dalam proses pembelajaran disekolah senantiasa diamalkan dalam kehidupan pergaulan sehari-hari oleh siswa disekolah maupun dimasyarakat serta berupaya memaknai dan menyayangi jasmani dan rohani, mampu beradaptasi dan hidup bersama dengan orang lain dan makhluk lain, menjaga lingkungan berbhakti kepada Tuhan Yang Maha Esa. Nilai-nilai karakter yang terkandung pada ajaran Tri Hita Karana juga merupakan bagian integral dari pengembangan sains dan teknologi yang dikembangkan melalui seluruh proses pembelajaran pada mata pelajaran yang sesuai dengan kurikulum yang berlaku di semua unit dan jenjang pendidikan sekolah. Guru disini sangat berperan dalam membangun nilai karakter siswa yaitu melalui: (1) kegiatan proses pembelajaran; (2) kegiatan keseharian dalam bentuk budaya sekolah; (3) kegiatan ko-kurikuler dan atau ekstra kurikuler; dan (4) kegiatan keseharian di rumah dan di masyarakat. Dalam proses pembelajaran di kelas pengembangan nilai karakter dilaksanakan dengan menggunakan pendekatan terintergrasi dalam semua mata pelajaran, terintegrasi dalam muatan lokal dan kegiatan pengembangan diri (Depdiknas 2011).

\section{Peran Guru Agama Hindu Dalam Menanamkan Nilai Tri Hita Karana}

Guru bermakna sebagai pendidik profesional dengan tugas utama mendidik, mengajar, membimbing, mengarahkan, melatih, menilai, dan mengevaluasi peserta didik pada jalur pendidikan formal. Sejalan dengan itu, guru memiliki peran yang bersifat multi fungsi, lebih dari sekedar yang tertuang pada produk hukum tentang guru. Profesionalitas yang dimiliki oleh seorang guru akan berpengaruh terhadap pembentukan karakter peserta didik. Dalam rangka lebih memperkuat pelaksanaan pendidikan karakter telah teridentifikasi 18 nilai yang bersumber dari agama, Pancasila, budaya, dan tujuan pendidikan nasional, yaitu: (1) Religius, (2) Jujur, (3) Toleransi, (4) Disiplin, (5) Kerja keras, (6) Kreatif, (7) Mandiri, (8) Demokratis, (9) Rasa Ingin Tahu, (10) Semangat Kebangsaan, (11) Cinta Tanah Air, (12) Menghargai Prestasi, (13) Bersahabat/Komunikatif, (14) Cinta Damai, (15) Gemar Membaca, (16) Peduli Lingkungan, (17) Peduli Sosial, \& (18) Tanggung Jawab (Pusat Kurikulum. Pengembangan dan Pendidikan Budaya Karakter Bangsa). Mengingat hal tersebut di atas, guru yang profesional dituntut memiliki komitmen, bertanggungjawab, belajar dari pengalaman, menjadi bagian dari masyarakat belajar, sehingga mampu meningkatkan karakter siswa. Sedangkan didalam Veda dan susastra Hindu sangat banyak digambarkan dan diulas bagaimana tugas dan kewajiban seorang guru, dan demikian besar peranan guru-guru rohani Hindu yang mengembangkan ajaran Agama Hindu yang dapat diwarisi dan digali dewasa ini, oleh karena itu dalam ajaran Agama Hindu seorang guru memiliki posisi sentral dan terhormat di tengah-tengah masyarakat.

Dalam hal ini, guru Agama Hindu memegang peranan yang sangat penting dalam pembentukan karakter siswa. Peran mata pelajaran Agama Hindu yang dibelajarkan di sekolah berlandaskan atas prinsip bahwa Ajaran Hindu adalah sebagai pandangan hidup pribadi pemeluknya dalam hubungannya dengan Ida Sang Hyang Widhi Wasa (Tuhan Yang Maha Esa). Peran pendidikan Agama Hindu lebih ditonjolkan kepada suatu sikap dalam kerangka menghargai manusia sebagai mahluk ciptaanNya, sebagai dirinya sendiri, dalam hubungannya dengan lingkungan baik lingkungan sosial dan alam. Hal tersebut selaras dengan pandangan Tri Hita Karana yang sangat dipegang teguh oleh pemeluk Hindu sebagai sebuah pandangan universal yang sudah ada sejak dahulu kala. Maka menjadi seorang guru baik itu guru Agama Hindu dituntut agar benar-benar menjadi guru yang profesional. 


\section{Persepsi Siswa}

Rahmat (1996: 51) mendefinisikan persepsi adalah pengalaman tantang obyek, peristiwa/hubungan yang diperoleh dengan menyimpulkan informasi dan menafsirkan pesan. Sedangkan Thoha (2010: 142) menyatakan bahwa, persepsi adalah suatu penafsiran yang unik terhadap situasi dan informasi, dan bukan hanya suatu pencatatan yang benar terhadap situasi atau informasi yang diperoleh. Sarwono (2012: 86) lebih lanjut mengungkapkan bahwa, persepsi berlangsung saat seseorang menerima stimulasi dari dunia luar yang ditangkap oleh organ- organ atau alat indria bantunya yang masuk ke dalam otak. Di dalamnya terjadi proses berpikir yang pada akhirnya terwujud dalam sebuah pemahaman. Berdasarkan pembahasan tersebut, peneliti menyimpulkan bahwa, persepsi merupakan tanggapan terhadap informasi atau kesan tentang suatu obyek yang diperoleh oleh individu melalui apa yang ditangkap oleh panca indera. Informasi yang diperoleh selanjutnya diorganisasi, di interpretasi, dan dievaluasi, sehingga memperoleh arti tentang suatu obyek. Berdasarkan pengertian persepsi oleh Walgito (2003: 54 -55), persepsi memiliki indikator, yaitu: (1) penyarapan, (2) pengertian dan pemahaman, dan (3) penilaian atau evaluasi.

\section{Metode}

Metode penelitian yang dipergunakan adalah metode penelitian kualitatif dengan mendekatkan pada teknik-teknik pendekatan kualitatif, antara lain teknik pengumpulan data melalui observasi (pengamatan langsung di objek penelitian), wawancara mendalam terhadap informan yang telah ditetapkan, dan studi dokumentasi. Objek dalam penelitian ini adalah sekolah SMK N 3 Singaraja, sedangkan subjeknya yaitu guru di SMK N 3 Singaraja kelas XI TIPTL. Data yang terkumpul selanjutnya dianalisis menggunakan metode deskriptif kualitatif.

\section{Hasil dan Pembahasan}

\section{A. Nilai Tri Hita Karana Belum Ditanamkan Secara Optimal di SMK N 3 Singaraja}

Pendidikan Agama Hindu di Bali tentunya diharapkan dapat melangsungkan karakteristik kehidupan dan potensi-potensi pokok kebudayaan Bali yang berbingkai pada ideologi masyarakat Bali, yaitu Tri Hita Karana. Idealnya, perilaku, tata krama, etika, cara berpikir dan cara berbicara generasi muda yang terdidik berlandaskan atas falsafah Tri Hita Karana. Di antaranya, tingginya segmen spiritualitas kehadapan Tuhan Yang Maha Esa. Kuatnya iman dan taqwa agar terhindar dari perbuatan yang tidak dikehendaki oleh agama sebagai bentuk aplikasi unsur Parahyangan. Di samping itu, perilaku, cara berpikir dan berbicara kepada sesama dan tingginya sikap saling menghormati, toleransi, sikap saling menghargai satu sama lain bahkan dengan sesama yang memiliki latar belakang agama, ras, adat, bahkan budaya juga terjaga dengan baik sebagai salah satu aplikasi dari unsur Pawongan. Sedangkan aplikasi unsur Palemahan, perilaku yang diidealkan adalah kebijaksanaan dalam mengelola alam dan lingkungan sekitar sehingga tetap terjaga kelestariannya.

Berdasarkan observasi dan wawancara yang dilakukan di sekolah SMK N 3 Singaraja nampak bahwa Tri Hita Karana belum sepenuhnya tertanam dalam kehidupan sehari-hari siswa di sekolah dari hubungan manusia dengan manusia, manusia dengan Tuhan dan manusia dengan lingkungan. Hasil observasi memperlihatkan bahwa telah terjadinya degradasi moral dimana siswa tidak lagi peduli dengan lingkungan (palemahan) sekitar. Setelah makan siswa lebih banyak membiarkan sampahnya berserakan ditempat mereka makan daripada membuangnya ditempat sampah. Padahal dari pihak sekolah sudah menyediakan tempat sampah di beberapa titik salah satunya yaitu di kelas masing-masing namun tetap saja siswa lebih memilih membuang sampah tidak pada tempat yang telah disediakan, maka tidak heran jika tiap sekolah ada petugas khusus untuk membersihkan sampah. Ini menandakan bahwa unsur Palemahan yaitu menjalin hubungan harmonis kepada alam dan lingkungan sekitar juga menurun. Dilihat dari unsur Parahyangan dari hasil pengamatan yang dilakukan nampak ada beberapa siswa yang terlambat namun disaat yang sama siswa tersebut terlihat tidak memiliki niat untuk mengejar waktu untuk ikut teman-temannya melakukan puja tri sandya dan cendrung berjalan santai pada saat siswa yang lain melaksanakan puja tri sandya (persembahyangan), ada beberapa siswa yang selalu bercanda saat melaksanakan tri sandya, hal tersebut terjadi hampir setiap hari saat dilakukannya observasi dan penelitian di lingkungan sekolah. Pawongan bisa terlihat dari bahwa siswa kurang menghargai guru yang sedang mengajar di dalam kelas, siswa terkadang tidur-tiduran saat guru mengajar dan tidak memperhatikan apa yang 
disampaikan oleh guru. Menurunnya rasa hormat (respect) siswa terhadap guru merupakan masalah umum yang tengah dihadapi oleh dunia pendidikan masa sekarang.

Belum optimalnya ditanamkan Tri Hita Karana di sekolah SMK N 3 Singaraja bisa dikaji dari faktor internal maupun faktor ekstermal. Faktor internalnya yaitu dimana sekolah sebagai lembaga pendidikan formal yang paling strategis sebagai pusat budaya sangat tepat untuk mengimplementasikan konsep Tri Hita Karana dalam membangun nilai karakter dan spiritualitas siswa. Oleh karen itu dalam menanamkan Tri Hita Karana disekolah, semua komponen (stake holders) harus dilibatkan termasuk komponen-komponen pendidikan itu sendiri yang meliputi: isi kurikulum, proses pembelajaran dan penilaian, kualitas hubungan, penanganan atau pengelolaan mata ajar, pengelolaan sekolah, pelaksanaan aktivitas atau kegiatan ko-kurikuler, pemberdayaan sarana prasarana, pembiayaan dan etos kerja seluruh warga dan lingkungan sekolah. Jadi disini peran guru agama sangat penting sekali dalam menanamkan nilai Tri Hita Karana kedalam proses belajar pembelajaran termasuk juga komponen perangkat pembelajaran.

\section{B. Implementasi Tri Hita Karana Sebagai Upaya Membangun Nilai Karakter Siswa Pada Proses Belajar mengajar di SMK N 3 Singaraja}

Peran pendidikan Agama Hindu lebih ditonjolkan kepada suatu sikap dalam rangka menghargai manusia sebagai mahluk ciptaanNya, sebagai dirinya sendiri, dalam hubungannya dengan lingkungan baik lingkungan sosial dan alam. Hal tersebut selaras dengan pandangan Tri Hita Karana yang sangat dipegang teguh oleh pemeluk Hindu sebagai sebuah pandangan universal yang sudah ada sejak dahulu kala. Maka menjadi seorang guru baik itu guru Agama Hindu dituntut agar benar-benar menjadi guru yang profesional. Peran guru dalam mengimplementasikan Tri Hita Karana dalam proses pembelajaran disekolah diharuskan dilakukan dalam kehidupan sehari-hari siswa disekolah maupun di lingkungan yaitu dengan cara menjaga hubungan antara manusia dengan Tuhan, manusia dengan manusia dan manusia dengan alam atau lingkungan.

Berdasarkan hasil penelitian terkait dengan peran guru agama hindu dalam membangun niali karakter siswa melalui implementasi nilai-nilai Tri Hita Karana maka hasil penelitian memperlihatkan bahwa dalam mengimplementasikan Tri Hita Karana sebagai upaya membangun nilai karakter siswa, maka guru sebagai pendidik harus mampu menggunakan berbagai pendekatan dan uapaya yang dapat membangun karakter siswa untuk selalu menjaga hubungan antara sesama (Pawongan), hubungan antara manusia dengan Tuhan (Parahyangan) dan hubungan antara manusia dengan lingkungan (Palemahan). Dalam implementasi berbagai upaya yang dilakukan dalam membangun karakter siswa diantaranya yaitu mengintegrasikan ke setiap mata pelajaran. Hasil penelitian memperlihatkan bahwa dalam proses belajar pembelajaran yang dilakukan oleh guru sudah diintegrasikan kedalam setiap pembelajaran hal ini terbukti dari sebelum pembelajaran berlangsung siswa melaksanakan doa bersama atau puja trisandya, hal tersebut merupakan salah satu contoh bentuk rasa hormat, cinta dan bentuk hubungan antara manusia dengan Tuhan. Selain itu guru selalu mengingatkan siswa untuk selalu membersihkan lingkungan yang dilakukan oleh siswa setiap harinya dan secara otomatis hal tersebut mewujudkan hubungan antara manusia dengan lingkungan. Hal yang terpenting yaitu mengintegrasikan nilai Tri Hita Karana tidak hanya secara teoritis namun bagaimana pelaksanaannya dalam keseharian siswa. Yang perlu diperhatikan oleh guru dalam mengintegrasikan Tri Hita Karana dalam membangun karakter siswa yaitu perangkat pembelajaran yang dimiliki oleh guru agama hindu karena kelengkapan perangkat pembelajaran menunjukan bahwa guru agama hindu di SMK N 3 Singaraja sudah melakukan persiapan sebelum melakukan proses belajar mengajar.

Selanjutnya berdasarkan hasil penelitian dapat diungkap bahwa guru dalam menanamkan nilai Tri Hita Karana melalui kegiatan keseharian dalam bentuk budaya sekolah seperti kegiatan rutin yang dilakukan oleh siswa di sekolah. Guru selalu membimbing siswa seperti membiasakan sembahyang bersama setiap awal sebelum jam pembelajaran dimulai dan setiap jam pulang, sembahyang setiap purnama dan Tilem. Selain itu adapun pengembangan budaya sekolah yang dilakukan yaitu kegiatan spontan yang mengajak siswa untuk memungut sumbangan atau suka duka. Hal tersebut jelas mampu menanamkan nilai karakter kepada siswa dan merupakan salah satu penerapan dari Tri Hita Karana yaitu hubungan antara manusia dengan manusia (Pawongan). Nilai karakter yang bisa diambil dari kegiatan spontan ini adalah nilai toleransi, demokratis, semangat kebangsaan, bersahabat/komunikatif, cinta damai, peduli sosial dan bertanggung jawab. 
Pengimplementasian Tri Hita Karana dalam pembentukan nilai karakter siswa bisa melalui kegiatan ekstra kulikuler. Kegiatan ekstra kulikuler ini terbukti mampu mengintegrasikan konsep Tri Hita Karana dalam kehidupan siswa dan membangun nilai karakter siswa seperti ekstra pesantian. Pesantian merupakan ekstra kulikuler yang mengajarkan siswa untuk lebih mendalami nyanyian-nyayian hindu yang biasanya dipergunakan dalam upacara-upacara seperti dewa yadnya dan hal tersebut sudah mengajarkan siswa terkait hubungan manusia dengan Tuhan (Parahyangan). Nilai karakter yang bisa diterapkan yaitu nilai religius. Selain itu ekstra lain yang mampu dalam membangun nilai karakter siswa yaitu pramuka.

\section{Persepsi Siswa Terhadap Tri Hita Karana Sebagai Landasan Budipekerti Dalam Ajaran Agama Hindu di SMK N 3 Singaraja}

\section{a. Penyerapan Informasi Atau Objek dari Luar Individu}

Dari hasil pengamatan dan observasi di kelas XI TIPTL pada tahap penyerapan informasi maka didapatkan hasil bahwa penyerapan materi nilai-nilai Tri Hita Karana yang diajarkan oleh guru agama hindu ketika proses pembelajaran berlangsung dari 30 orang siswa menunjukan bahwa $100 \%$ siswa telah mampu menyerap informasi yang diberikan oleh guru dan hal tersebut menunjukan bahwa siswa menerima apa yang dijelaskan oleh guru terkait dengan materi yang disampaikan dan sudah mengena pada konsep Tri Hita Karana.

\section{b. Pengertian atau Pemahaman Siswa}

Dalam pengertian atau pemahaman mengenai nilai-nilai Tri Hita Karana menunjukan bahwa hanya $67.7 \%$ siswa mengerti nilai-nilai Tri Hita Karana yang disampaian guru saat pembelajaran berlangsung dengan alasan karena materi yang disampaikan kebanyakan tentang materi Wiwaha sehingga guru tidak banyak menyampaikan ajaran Tri Hita Karana. Namun dari tanggapan siswa terkait alasan siswa dapat menerima materi karena siswa gampang memahami adanya keterkaitan antara nilai-nilai Tri Hita Karana dengan pembentukan karakter siswa melalui pembelajaran agama hindu dengan alasan

\section{c. Penilaian dan Evaluasi Siswa}

Berdasarkan hasil penelitian penilaian dan evaluasi siswa diketahui bahwa, hampir sebagian siswa tidak dapat menyerap informasi terbukti dari presentase siswa hanya mencapai $57.5 \%$ yang bisa menangkap informasi. Penyebab kurangnya pemahamani siswa tersebut adalah karena siswa tidak terlalu memahami tentang cara menyelesaikan permasalahanpermasalahan hidup melalui nilai-nilai Tri Hita Karana. Sedangkan hal yang membuat siswa dapat memahami materi adalah dari persepsi siswa atas penilaian tersebut, bukti dari alasan yang disampaikan oleh siswa adalah bahwa perilaku sehari-hari yang dilakukan berdasar nilainilai Tri Hita Karana akan membawa seseorang menuju kebahagiaan dan kedamaian karena dengan menjaga hubungan kepada semua mahluk maka semua mahluk akan memberikan kebahagiaan untuk orang tersebut. Pernyataan tersebut membuktikan bahwa, penilaian siswa terkait nilai-nilai Tri Hita Karana dirasakan penting oleh siswa untuk diterapkan di kehidupan sehari-hari.

Dari semua total hasil presentase yang dikumpulkan menunjukan angka $75.1 \%$ dari $100 \%$ yang berarti siswa di kelas XI TITPL I menyatakan memperoleh manfaat atas ajaran Tri Hita Karana pada mata pelajaran agama hindu walau tidak maksimal. Persepsi siswa atas penilaian tersebut juga menunjukan bahwa siswa telah cukup memahami apa yang telah siswa peroleh dengan menunjukan beberapa manfaat yang ditemukan oleh siswa dari proses pembelajaran tersebut.

\section{Simpulan dan Saran}

Berdasarkan hasil yang diperoleh, dapat disimpulkan bahwa: 1) Penanaman nilai-nilai Tri Hita Karana di SMK N 3 Singaraja belum optimal dapat ditinjau dari masalah-masalah yang ada dilapangan seperti ketidak pedulian siswa terhadap lingkungan tidak hormat terhadap guru, seringnya bermain-main pada saat sembahyang. Guru Agama Hindu mempunyai peranan sangat penting dalam penanaman nilai Tri Hita Karana kepada siswa disekolah.Dikatakan belum optimalnya ditanamkan Tri Hita Karana di sekolah SMK N 3 Singaraja bisa dikaji dari faktor internal maupun faktor ekstermal. 2) Dalam implementasi konsep Tri Hita Karana sebagai upaya dalam membangun karakter siswa maka guru sebagai tenaga pendidik harus mampu menggunakan berbagai upaya dalam membangun karakter siswa diantaranya yaitu 
mengintegrasikan ke setiap materi pelajaran. Selain itu guru juga melakukan pengembangan budaya sekolah, pengembangan budaya sekolah dilakukan melalui kegiatan pengembangan diri sendiri seperti kegiatan rutin, maksudnya yaitu kegiatan yang dilakukan siswa secara terus menerus seperti selalu mengingatkan siswa untuk sembahyang bersama atau puja trisandya. Adapun pengembangan budaya sekolah yang dilakukan yaitu kegiatan spontan yang mengajak siswa untuk memungut sumbangan atau suka duka. Selain itu bisa melalui kegaiatan ekstra kurikuler seperti pramuka, pesantian, mapala. Hal tersebut jelas mampu menanamkan nilai karakter kepada siswa dan merupakan salah satu penerapan dari Tri Hita Karana yaitu hubungan harmonis antara manusia dengan manusia (Pawongan), manusia dengan Tuhan dan manusia dengan lingkungan. 3) Persepsi siswa terhadap Tri Hita Karana sebagai landasan budipekerti dalam ajaran agama hindu ditanggapi siswa dengan respon yang kurang cukup baik, hal ini terbukti $75.1 \%$ siswa di kelas XI TITPL I menyatakan memperoleh manfaat atas ajaran Tri Hita Karana pada mata pelajaran agama hindu. Persepsi siswa atas penilaian tersebut juga menunjukan bahwa siswa telah menilai dan cukup memahami apa yang telah siswa peroleh dengan norma yang dimiliki siswa dengan menunjukan beberapa manfaat yang ditemukan oleh siswa dari proses pembelajaran tersebut.

Saran yang dapat diberikanpeneliti yaitu: 1) Bagi Guru, Guru diharapkan agar lebih memberikan perhatian pada persiapan dan metode mengajar siswa dimana dalam persiapan tersebut akan memberikan materi yang lebih kaya yang disesuaikan dengan keadaan siswa. 2) Bagi Siswa Pengembangan materi nilai-nilai Tri Hita Karana dalam pelajaran agama hindu dalam skala yang lebih luas akan mampu membentu siswa dalam menggali dan memahami nilai-nilai Tri Hita Karana secara mendasar. Dalam penerapan ajaran nilai-nilai Tri Hita Karana jangka panjang akan membantu merubah karakter siswa sedikit demi sedikit sehingga calon generasi muda yang berkualitas secara akademik serta terpuji dalam perilaku akan lebih banyak terlahir, terutama dari SMK N 3 Singaraja. 3) Bagi peneliti Berikutnya, Pengembangan peran guru pendidikan agama hindu dalam membangun nilai karakter siswa melalui implementasi Tri Hita Karana dapat dikembangkan disekolah lain untuk menganalisis perbedaan dan persamaan dari hasil pengembangan.

\section{Daftar Pustaka}

Aryadharma, Ni Kadek Surpi. 2005. Melahirkan Generasi Berkarakter Dewata. Kiat sukses Siswa Menurut Hindu. Denpasar: Pustaka Bali Post.

Dalyono, M. 1997. Psikologi Pendidikan. Jakarta: PT.Rineka Cipta

Depdiknas. 2011. Model Silabus dan Rencana Pelaksanaan Pembelajaran Pendidikan Agama Hindu. Jakarta: Badan Standar Nasional Pendidikan.

http://www.sarjanaku.com/2011/08/pengertian-kesulitanbelajar.html. Diakses pada tanggal 3 Mei 2016

Pageh, I Made. 2010. Filsafat Sejarah. Undiksha: Singaraja.

Parimartha, I Gede. 2011. Nilai Karakter Bangsa Dan Aktualisasinya Dalam Kehidupan Masyarakat Bali. Denpasar: Udayana University Press

Rahmat, Jalaludin. (1996). Psikologi Komunikasi. Bandung: PT Remaja Rosdakarya.

Sarwono, Sarlito W. (2012). Pengantar Psikologi Umum. Jakarta: PT Raja Grafindo Persada

Thoha, Miftah. (2010). Perilaku Organisasi, Konsep Dasar dan Aplikasi. Jakarta: PT Raja Grafindo Persada.

Walgito, Bimo. 2003. Psikologi Sosial. Yogyakarta. C.V Andi Offset.

Wiana, I Ketut. 2007. Tri Hita Karana Menurut Konsep Hindu. Surabaya: Paramita. 